\title{
PERISSOCYTHERIDEA CARRENOAE SP. NOV. (CRUSTACEA, OSTRACODA) AND ASSOCIATED CALCAREOUS MICROFAUNA FROM YECUA FORMATION (MIOCENE), BOLIVIA
}

\author{
DEMÉTRIO DIAS NICOLAIDIS \\ Laboratório de Micropaleontologia, Programa de Pós-Graduação em Geologia, UNISINOS, Av. Unisinos, 950, 93022-000, \\ São Leopoldo, RS, Brazil.demetrion@unisinos.br \\ JOÃO CARLOS COIMBRA \\ Departamento de Paleontologia e Estratigrafia, Instituto de Geociências, UFRGS, 91501-970, Cx.P. 15001, Porto Alegre, \\ RS,Brazil.joao.coimbra@ufrgs.br
}

\begin{abstract}
The Yecua Formation (Middle-Late Miocene) is located in the sub-Andean belt in Bolivia, where it is exposed in stream beds and road cuts. The material herein studied came from La Angostura outcrop $60 \mathrm{~km}$ from the town of Santa Cruz de La Sierra, just after a short bridge over the Piray River. The calcareous microfossil assemblage comprises five ostracode species: Cypria aff. C. aqualica, Cyprideis spp., Darwinula sp., Ilyocypris? sp. and Perissocytheridea carrenoae sp. nov.; the foraminifer Ammonia beccarii f. tepida; and two unindentified species of the gastropod Heleobia. Although the existence of brackish water and freshwater environments herein identified has been supported by previous authors, it is the first time that a freshwater calcareous microfauna in the Yecua Formation is recorded. Finally, a discussion is presented on the depositional setting and paleogeography of this lithostratigraphical unit.
\end{abstract}

Key words: Yecua Formation, Bolivia, Paranense Sea, ostracods, foraminifers, gastropods, paleoecology.

\begin{abstract}
RESUMO - A Formação Yecua (Mioceno Médio-Tardio) está localizada no cinturão sub-Andino, Bolívia, onde está exposta em leitos de rios e cortes de estrada. O material aqui estudado é oriundo de um afloramento da seção de La Angostura a 60 km da cidade de Santa Cruz de la Sierra, após uma pequena ponte sobre o rio Piray. A associação de microfósseis calcários é composta por cinco espécies de ostracodes: Cypria aff. C. aqualica, Cyprideis spp., Darwinula sp., Ilyocypris? sp. e Perissocytheridea carrenoae sp. nov.; o foraminífero Ammonia beccarii f. tepida; e duas espécies não identificadas do gastrópode Heleobia. Embora os ambientes mixohalinos e de água doce aqui identificados já tenham sido apontados por outros autores, é a primeira vez que uma fauna dulceaquícola de microfósseis calcários é registrada para a Formação Yecua. Por fim, é apresentada uma discussão sobre o ambiente deposicional e a paleogeografia desta unidade litoestratigráfica.
\end{abstract}

Palavras-chave: Formação Yecua, Bolívia, Mar Paranense, ostracodes, foraminíferos, gastrópodes, paleoecologia.

\section{INTRODUCTION}

The Yecua Formation (Chaco Basin) was proposed by Padula \& Reyes (1958) who designated the Quebrada outcrop as the type section. After this first paper, few authors have worked on the geology and paleontology of the Chaco Basin (e.g.: Branisa, 1970; Marshall et al., 1993; Alonso, 2000; Marengo, 2000; Aceñolaza \& Sprechmann, 2002; Uba, 2005), most of them only in a larger context, i.e., dealing with the marine transgression that took place in western South America during the Miocene. Hulka et al. (2006) presented the most recent paper on this subject, which deals with the depositional settings, paleogeography and age of this Middle-Late Miocene formation. Unfortunately, as discussed later in the present paper, the results and conclusions reported by Hulka et al. (2006) and co-authors should be taken with some caution.

This article describes a new ostracode species, Perissocytheridea carrenoae, and presents the paleoenvironmental significance of some calcareous microfossils recovered from an outcrop in La Angostura section (18 $\left.18^{\circ} 4.68^{\prime \prime} \mathrm{S} ; 63^{\circ} 31^{\prime} 8.47^{\prime \prime} \mathrm{W}\right)$ located $60 \mathrm{~km}$ from the town of Santa Cruz de La Sierra, just after a short suspension footbridge over the Piray River (Figure 1). The material studied was collected by the second author during a fieldwork trip in 2002. Although only four samples were analyzed herein (Figure 2), three of them showed an abundant non-marine microfauna consisting of five ostracode species, one foraminifer and two small gastropods. The preparation of the samples was according to standard methods. Specimens were illustrated using a SEM JEOL - JSM 6060 from the Electron Microscopy Center at the Universidade Federal do Rio Grande do Sul (UFRGS), Porto Alegre, Brazil.

The material is housed in the section of Ostracoda (MPO) of the collections of the Museu de Paleontologia, UFRGS, Porto Alegre. The Ostracoda taxonomy follows mostly that of Liebau (2005). 


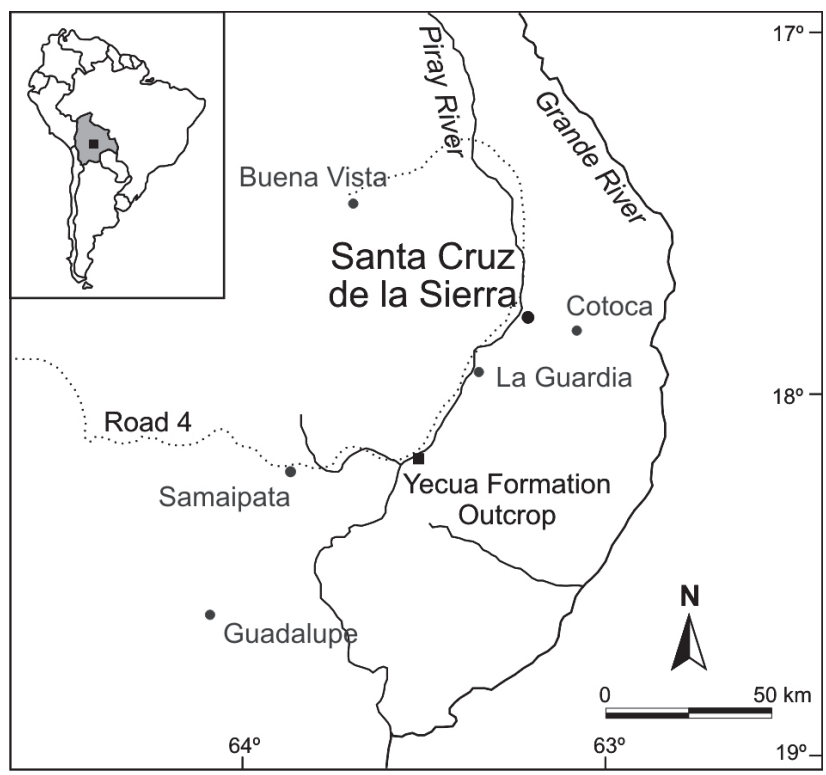

Figure 1. Location of the La Angostura outcrop, Yecua Formation, Bolivia.

\section{OSTRACODA TAXONOMY}

Superfamily CYTHERIDEOIDEA Liebau, 2005

Family CYTHERIDEIDAE Sars, 1925

Subfamily PERISSOCYTHERIDEINAE Bold, 1963

Genus Perissocytheridea Stephenson, 1938

Perissocytheridea carrenoae sp. nov.

(Figure 3A-F)

Holotype. MP-O-2081, female carapace, 1: $0.46 \mathrm{~mm}$, h: $0.26 \mathrm{~mm}$, w: $0.20 \mathrm{~mm}$, sample M0304-N.

Paratypes. MP-O-2082, female carapace, 1: $0.47 \mathrm{~mm}$, h: 0.26 $\mathrm{mm}$, w: $0.21 \mathrm{~mm}$, sample M0304-N; MP-O-2083, male carapace, 1: $0.49 \mathrm{~mm}$, h: $0.26 \mathrm{~mm}$, w: $0.23 \mathrm{~mm}$, sample M0304-N; MP-O2084, juvenile female carapace, $1: 0.40 \mathrm{~mm}$, h:0.23 mm, w: 0.19 $\mathrm{mm}$, sample M0304-N; MP-O-2085, female carapace, $1: 0.42 \mathrm{~mm}$, h: $0.25 \mathrm{~mm}$, w:0.20 mm, sample M0304-N; MP-O-2086, male carapace, 1: $0.50 \mathrm{~mm}$, h: $0.26 \mathrm{~mm}$, w: $0.23 \mathrm{~mm}$, sample M0304-N. Type locality. Outcrop in La Angostura section (18 $10^{\circ} 4.68^{\prime \prime} \mathrm{S}$; $\left.63^{\circ} 31^{\prime} 8.47^{\prime \prime W}\right), 60 \mathrm{~km}$ to SW from town of Santa Cruz de La Sierra (Bolivia), road number 4, just after a short suspension footbridge over Piray River.

Etymology. In honor of Ana Luisa Carreño in recognition of her significant contribution on calcareous microfossils from Latin America.

Material. See Table 1.

Diagnosis. Carapace small, subpyriform to subrectangular in lateral view. Greatest height at the eye tubercle and somewhat larger than half the length. Posterior margin narrow and rounded. Oral incurvature poorly developed and obscured by the delicate posteroventral alar process. Double median sulci strong; polygonal reticulae well developed with smooth solae. Reticulations with less developed muri in the central and posterodorsal regions.
Description. Carapace small, subpyriform to subrectangular in lateral view. Left valve larger than right. Maximum height at the eye tubercle and somewhat larger than half the length. Anterior margin widely rounded. Posterior margin narrow and more rounded in the left valve. Dorsal margin almost straight. Ventral margin with poorly developed oral incurvature and slightly obscured by the tumidity of the delicate posteroventral alar process. Sulcus bifurcate, strongly developed, bordering an elongate protuberance. Surface coarsely reticulate; roughly hexa- or pentagonal reticulae; solae smooth. Reticulation with less developed muri in the central and posterodorsal regions. Internal features not observed. Sexual dimorphism pronounced with male carapace more inflated posteriorly and more subrectangular than the female one. In dorsal view, female somewhat sagittate, while male lateral margins diverge slightly to greatest thickness posteriorly.

Distribution. The specimens were found in a single sample (M0304-N), La Angostura outcrop, Bolivia.

Remarks. Despite the relatively large number of Neogene fossil species of Perissocytheridea in both South and Central America, the authors are convinced that $P$. carrenoae differs in outline and ornamentation from all previously described species (see the following papers and references therein:

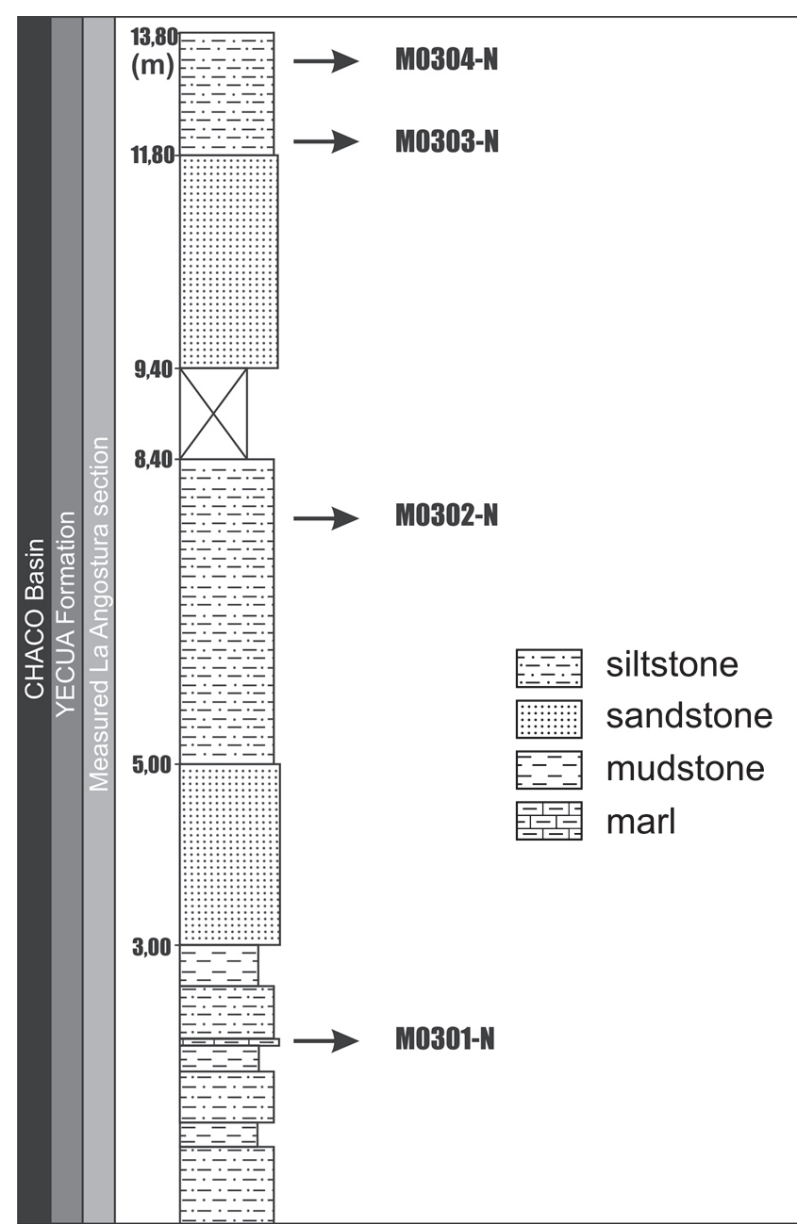

Figure 2. Litology of the La Angostura outcrop and study samples. 


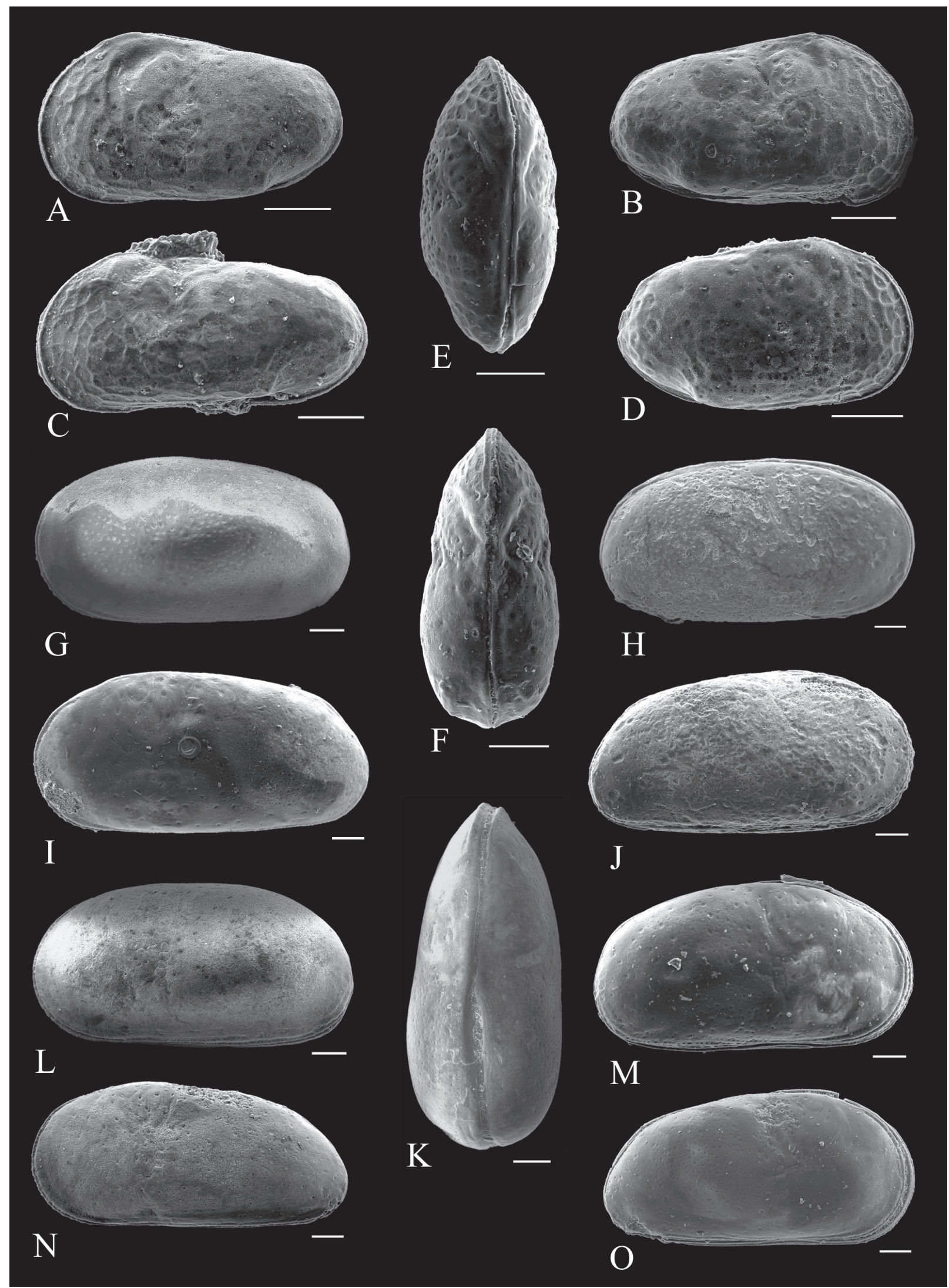

Figure 3. A-F, Perissocytheridea carrenoae sp. nov.: A, female left view, MP-O-2081, holotype; B, female right view, MP-O-2082, paratype; C, male left view, MP-O-2083, paratype; D, juvenile female right view, paratype, MP-O-2084; E, female dorsal view, paratype, MPO-2085; F, male dorsal view, paratype, MP-O-2086; G-O, Cyprideis spp.: G, female left view, MP-O-2087; H, female right view, MP-O-2088; I, male left view, MP-O-2089; J, male right view, MP-O-2090; K, female dorsal view, MP-O- 2091; L, female left view, MP-O-2092; M, female right view, MP-O-2093; N, male left view, MP-O-2094; O, male right view, MP-O-2095. Scale bars $=100 \mu \mathrm{m}$. 
Zabert, 1978; Purper, 1979; Sheppard \& Bate, 1980; MuñozTorres et al., 1998). The most similar species, P. kroemmelbeini Pinto \& Ornellas, 1970, is larger and more inflated; the female carapace possesses a well-developed alar process, and it is typically sagittate in dorsal view; the double sulci and reticulae are peculiar for each species.

\section{Subfamily CYTHERIDEINAE Sars, 1925 \\ Genus Cyprideis Jones, 1857 \\ Cyprideis spp.}

(Figures 3G-O, 4A-F)

Material. See Table 1.

Figured specimens. MP-O-2087, female carapace, 1: $0.88 \mathrm{~mm}$, h: $0.46 \mathrm{~mm}$, sample M0304-N; MP-O-2088, female carapace, 1: $0.95 \mathrm{~mm}$, h: $0.50 \mathrm{~mm}$, sample M0304-N; MP-O-2089, male carapace, 1: $0.94 \mathrm{~mm}$, h: $0.45 \mathrm{~mm}$, sample M0304-N; MP-O2090, male carapace, 1: $1.01 \mathrm{~mm}, \mathrm{~h}: 0.50 \mathrm{~mm}$, sample M0304-N; MP-O-2091, female carapace, $1: 0.86 \mathrm{~mm}$, w: $0.38 \mathrm{~mm}$, sample M0304-N; MP-O-2092, female carapace, 1: $0.80 \mathrm{~mm}$, h: 0.40 mm, sample M0303-N; MP-O-2093, female carapace, 1: 0.92 $\mathrm{mm}, \mathrm{h}: 0.49 \mathrm{~mm}$, sample M0303-N; MP-O-2094, male carapace, 1: $0.98 \mathrm{~mm}$, h: $0.45 \mathrm{~mm}$, sample M0303-N; MP-O-2095, male carapace, 1: $0.99 \mathrm{~mm}$, h: $0.49 \mathrm{~mm}$, sample M0303-N; MP-O2096, male carapace, $1: 0.91 \mathrm{~mm}$, w: $0.40 \mathrm{~mm}$, sample M0303-N; MP-O-2097, female carapace, l: $0.94 \mathrm{~mm}$, h: $0.51 \mathrm{~mm}$, sample M0302-N; MP-O-2098, female carapace, 1: 0.95 mm, h: 0.52 $\mathrm{mm}$, sample M0302-N; MP-O-2099, male carapace, $1: 0.97 \mathrm{~mm}$, h: $0.47 \mathrm{~mm}$, sample M0302-N; MP-O-2100, male carapace, 1 : $0.98 \mathrm{~mm}$, h: $0.48 \mathrm{~mm}$, sample M0302-N; MP-O-2101, female h: $0.34 \mathrm{~mm}$, sample M0302-N.

Distribution. Cyprideis spp. were recorded in the follow samples: M0302-N, M0303-N and M0304-N. La Angostura outcrop, Bolivia.

Remarks. Although more than one thousand caparaces of both adults and juveniles of Cyprideis spp. have been recovered from the samples analyzed herein, the majority of them are extremely recrystallized, hindering a detailed identification. Surprisingly, Hulka et al. (2006), studying calcareous microfossils from the same outcrop, identified three different species: $C$. aff. C. torosa (Jones, 1850), C. aff. $C$. amazonica Purper, 1979 and C. aff. C. truncata Purper, 1979, all of them at the base of this outcrop. However, in spite of the poor quality of the photographs presented by them, at least two morphological features are easily discernible among these ostracodes, and both disagree with the identification mentioned just above. Specimens of Hulka et al. (2006) are much smaller and show a different outline when compared with the original diagnosis and descriptions. Unfortunately, among the four samples studied in the present paper, only one (M0301-N) was recovered from the base of the section, and it was barren. In our opinion, the species of Cyprideis from both middle and top of the La Angostura outcrop (samples M0302-N, M0303-N and M0304-N) are very disctinct from all species described by Purper (1979), Sheppard \& Bate (1980), Purper \& Pinto (1983), Purper \& Ornellas (1991), Muñoz-Torres et al. (1998), Swain (1998) and Ramos (2006) from the Neogene Pebas/Solimões Formation in Brazil, Colombia and Peru. Besides, this complex of Cyprideis species does not show any morphological similarity with the species described for the Neogene from the south of South America by Rossi de García (1966), Bertels \& Zabert (1980) and Sanguinetti et al. (1992). Finally, a comparison with Caribbean Neogene Cytherideinae species, most of them discussed and figured by Bold (1976), reinforced our notion that La Angostura outcrop probably shows two or three endemic species of Cyprideis.

Superfamily CYPRIDOIDEA Baird, 1845

Family CYCLOCYPRIDIDAE Kaufmann, 1900

Genus Cypria Zenker, 1854

Cypria aff. C. aqualica Sheppard \& Bate 1980

(Figure 4G- H)

Material. See Table 1.

Figured specimens. MP-O- 2103, carapace, 1: $0.48 \mathrm{~mm}$, h: 0.31 $\mathrm{mm}$, sample M0302-N; MP-O-2104, carapace, 1: $0.50 \mathrm{~mm}$, h: $0.34 \mathrm{~mm}$, sample M0302-N.

Distribution. Cypria aff. C. aqualica was found only in the sample M0302-N from La Angostura outcrop, Bolivia.

Remarks. Although this species is abundant and displays an assemblage consisting of both adults and a suite of juveniles, the carapaces underwent conspicuous recrystallization. Cypria aff. C. aqualica is smaller and shows few differences in outline with the specimens of C. aqualica from Peru and Colombia (see Sheppard \& Bate, 1980) and Brazil (see Ramos, 2006).

Family ILYOCYPRIDIDAE Kaufmann, 1900 Subfamily ILYOCYPRIDINAE Kaufmann, 1900 Genus Ilyocypris Brady \& Norman, 1889 Ilyocypris? sp.

(Figure 4I-J)

Material. See Table 1.

Figured specimens. MP-O-2105, carapace, 1: $0.42 \mathrm{~mm}$, h: 0.24 $\mathrm{mm}$, sample M0302-N; MP-O-2106, carapace, $1: 0.50 \mathrm{~mm}$, h: $0.27 \mathrm{~mm}$, sample M0302-N.

Distribution. The specimens were recovered from a single sample (M0302-N), La Angostura outcrop, Bolivia.

Remarks. This species is relatively rare and all specimens are strongly recrystallized. The outline and the few developed double sulci in the central dorsal region allow its previous arrangement in Ilyocypris.

Superfamily DARWINULOIDEA Brady \& Norman, 1889 Family DARWINULIDAE Brady \& Normann, 1889 Genus Darwinula Brady \& Robertson, 1885 Darwinula sp. (Figure 4K-L)

Material. See Table 1.

Figured specimens. MP-O-2107, carapace, 1: $0.60 \mathrm{~mm}$, h: 


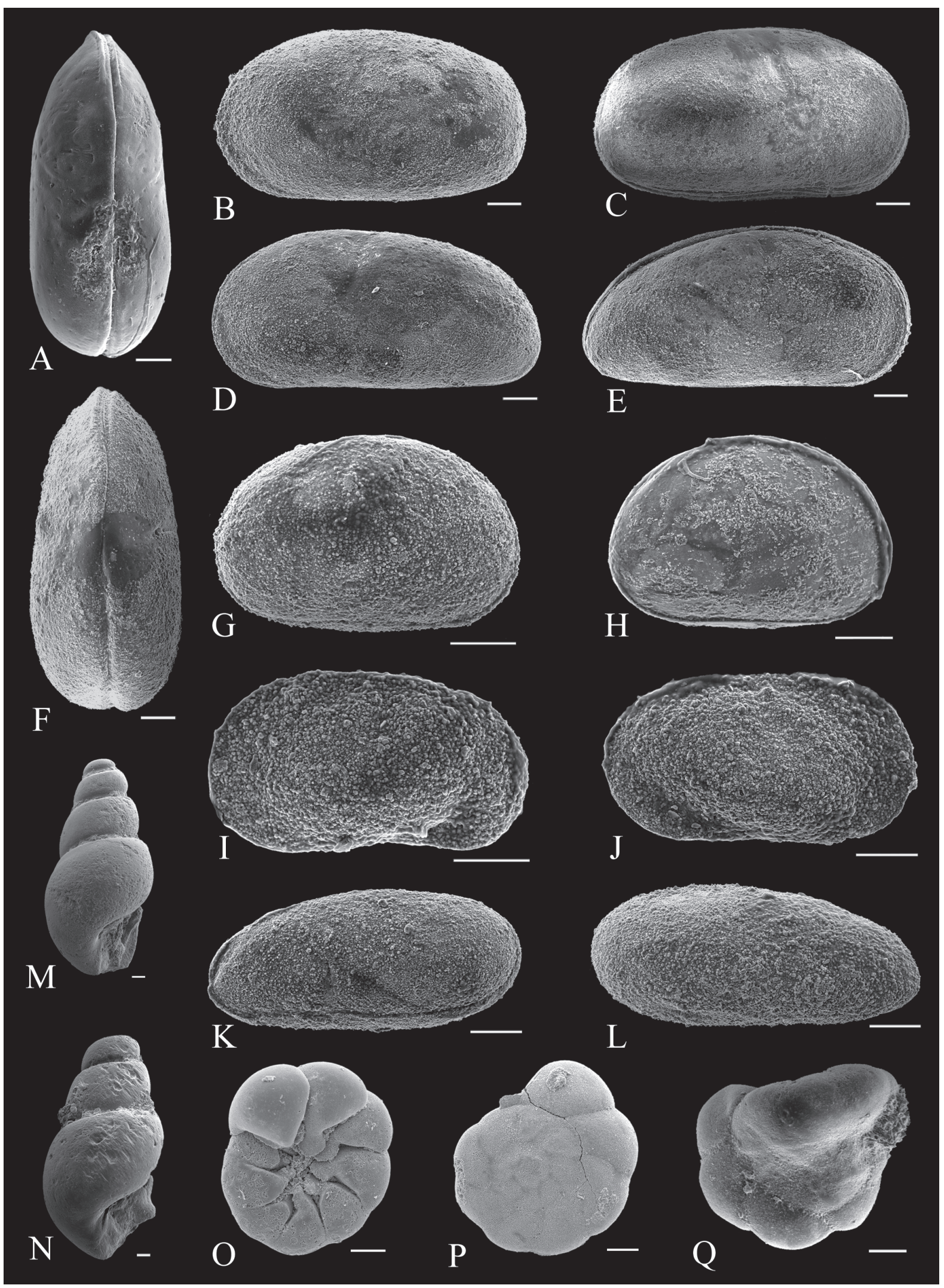

Figure 4. A-F, Cyprideis spp.: A, male dorsal view, MP-O-2096; B, female left view, MP-O-2097; C, female right view, MP-O-2098; D, male left view, MP-O-2099; E, male right view, MP-O-2100; F, female dorsal view, MP-O-2101; G, H, Cypria aff. C. aqualica Sheppard \& Bate 1980: G, left view, MP-O- 2103; H, right view, MP-O-2104; I, J, Ilyocypris? sp.: I, left view, MP-O-2105; J, right view, MP-O-2106; K, L, Darwinula sp.: K, left view, MP-O-2107; L, right view, MP-O-2108; M, Heleobia sp. 1, MP-I-7153; N, Heleobia sp. 2, MP-I-7154; O-Q, Ammonia beccarii f. tepida Cushman 1926: O, umbilical side, MP-F-3130; P, spiral side, MP-F-3131; Q, spiral side, deformed test, MP-F3132. Scale bars $=10 \mu \mathrm{m}$. 
Table 1. Microfossils and gastropods and their relative abundances in each sample. Abbreviations: $\mathbf{R}$, rare (10 or less); C, comum (between 11 and 100); A, abundant (between 101 and 300); VA, very abundant (more than 300 ).

\begin{tabular}{|c|c|c|c|c|}
\hline Taxa & \multicolumn{4}{|c|}{ Samples } \\
\hline Ostracodes & M0301-N & M0302-N & M0303-N & M0304-N \\
\hline Cypria aff. C. aqualica & & A & & \\
\hline Cyprideis spp. & & VA & VA & VA \\
\hline Darwinula sp. & & C & & \\
\hline Ilyocypris ? sp. & & C & & \\
\hline $\begin{array}{l}\text { Perissocytheridea } \\
\text { carrenoae sp. nov. }\end{array}$ & & & & A \\
\hline Foraminifer & & & & \\
\hline $\begin{array}{l}\text { Ammonia beccarii } \mathrm{f} \text {. } \\
\text { tepida }\end{array}$ & & & VA & VA \\
\hline Gastropods & & & & \\
\hline Heleobia sp. 1 & & & & $\mathrm{R}$ \\
\hline Heleobia sp. 2 & & & & $\mathrm{R}$ \\
\hline
\end{tabular}

$0.26 \mathrm{~mm}$, sample M0302-N; MP-O-2108, carapace, $1: 0.65 \mathrm{~mm}$, h: $0.28 \mathrm{~mm}$, sample M0302-N.

Distribution. Darwinula sp. is common only in the sample M0302-N, La Angostura outcrop, Bolivia.

Remarks. In spite of the general similarity between Darwinula sp. and D. fragilis Purper, 1979, in the Bolivian species the right valve is larger, overlapping the left one along the free margin. Besides, there is some difference in outline between these two species. Unfortunately, all specimens of Darwinula sp. are recrystalized hindering a detailed description and a specific indentification.

\section{PALEOECOLOGY}

The calcareous microfossil assemblage comprises at least five ostracode species: Perissocytheridea carrenoae sp. nov., Cyprideis spp., Cypria aff. C. aqualica, Ilyocypris? sp., Darwinula sp.; one species of the foraminifer Ammonia, A. beccarii f. tepida; and two unindentified species of the gastropod Heleobia (Table 1). Of the four samples studied, only one was barren (M0301-N). The gastropod fauna is represented by four internal molds and many fragments. On the other hand, $A$. beccarii f. tepida was very abundant and showed some deformed specimens.

The distribution of calcareous microfossils in the three fertile samples reveals two distinct paleoenvironments. The lowermost (sample M0302-N) was represented by a freshwater ostracode assemblage composed of Cypria sp., Darwinula sp. and Ilyocypris? sp. The euryhaline genus Cyprideis is also represented in this sample with two or three probably new species (see Ostracoda Taxonomy). Although Cyprideis is more common in brackish water, it has been extensively recorded in freshwater lakes (Wouters \& Martens, 1992, 1994) and paleolakes (Ramos, 2006). The presence of thin-shelled and fragile ostracode genera and male and female carapaces, as well as juveniles, strongly suggests a lack of substantial post-mortem transport and low-energy environmental deposits.

The other two fertile samples (M0303-N and M0304-N), both recovered near the top of the sequence (Figure 2), were characterized by the presence of typical brackish water calcareous microfauna. The first one is the most poorly diversified with only the ostracodes Cyprideis spp. and the foraminifer $A$. beccarii f. tepida, both very abundant. The sample M0304-N is more diversified and, besides the two species newly mentioned, possesses three others as follows: the ostracode $P$. carrenoae sp. nov. and the gastropods Heleobia sp. 1 and sp. 2. The abundance of these microfossils (with exception of only Heleobia spp.) and the presence of many well-preserved ontogenetic stages in the ostracod assemblages, clearly indicates an authochthonous fauna. The presence of rare internal molds of Heleobia may have more than one interpretation. It is uncertain whether this is better understood as transport from a nearby freshwater stream or as a deposition in situ of euryhaline species. The brackish water environmental interpretation is also supported by the presence of deformed tests of the well-known euryhaline cosmopolitan foraminifer species $A$. beccarii f. tepida, as already discussed by Madeira-Falcetta (1974), Boltovskoy (1990) and Geslin et al. (1998).

In relation to the barren sample (M0301-N), that was collected from a white marl layer, there is no sufficient evidence for a reliable environmental interpretation.

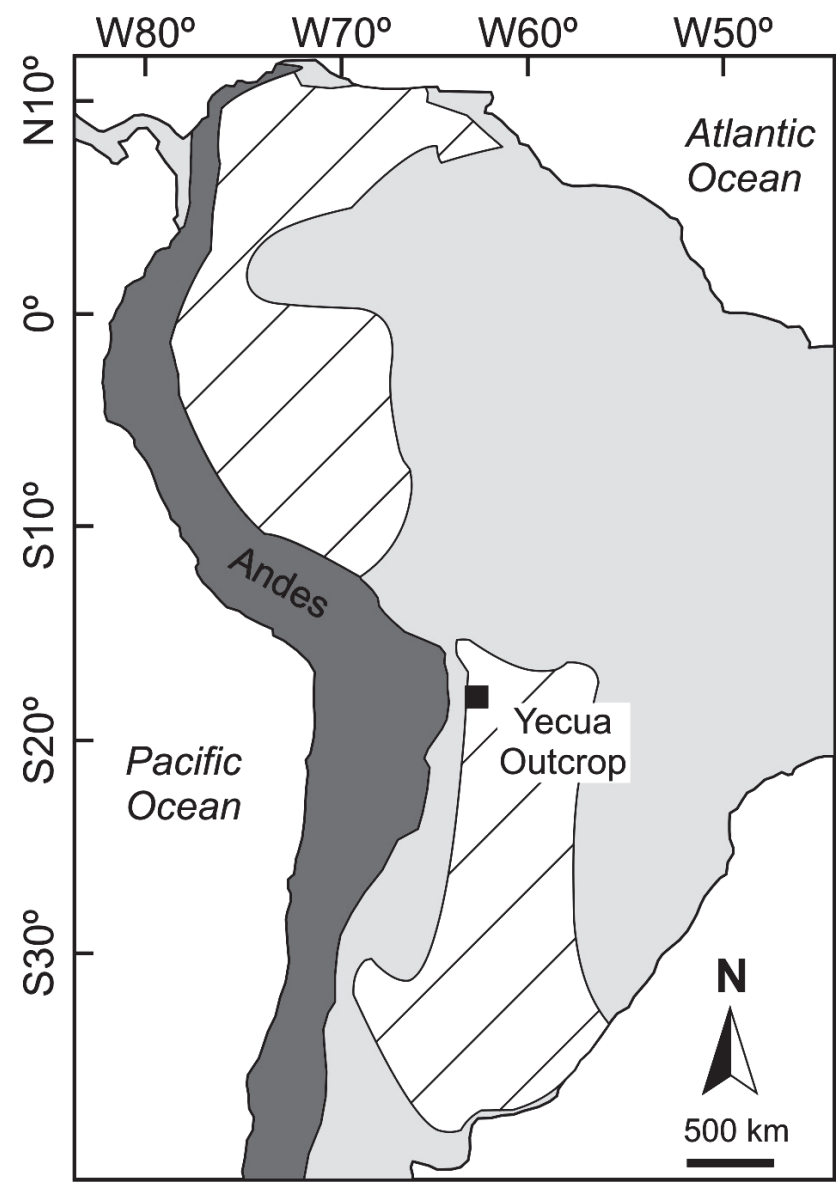

Figure 5. Map of South America showing the Amazonian (north) and Paranense (south) epicontinental seas extension (ruled areas). Study area is marked with a square (modified from Hovikoski et al., 2007). 


\section{DISCUSSION AND CONCLUSIONS}

Although the non-marine environment identified herein for an outcrop of the Yecua Formation has been supported by other authors, this is the first report of a freshwater calcareous microfauna in this lithostratigraphical unit. The continental deposits identified by previous authors were based on fishes, mammals and continental plant remains, and all of them were represented by outcrops situated above the latitude $18^{\circ} \mathrm{S}$, i.e., up to the north boundary of the Paranense Sea (Marshall et al., 1993; Alonso, 2000; Marengo, 2000).

The Paranese Sea (= Entrerriense Sea) has been studied by many authors whose conclusions have pointed to the Yecua Formation as the northernmost expression of a broad Middle-Late Miocene transgression event (Alonso, 2000; Marengo, 2000; Aceñolaza \& Sprechmann, 2002). This epicontinental sea (Figure 5) was related to the global high sea level events well known in the Oligocene and up to the Middle-Late Miocene. However, although transgressive pulses may be recognized by similar lithostratigraphical features, their regional correlation is hindered due to the diachronous nature of their deposits. Consequently, the modern literature has shown different scenarios for the possible geographical connections of the Yecua Formation with the adjacent coeval formations (e.g., Boltovskoy, 1991; Marshall et al., 1993; Sempere, 1995; Alonso, 2000; Marengo, 2000; Aceñolaza \& Sprechmann, 2002; Hulka et al., 2006; Hovikoski et al., 2007).

Unfortunately, the most recent study on the Yecua Formation, which was carried out by Hulka et al. (2006), shows many mistakes in its micropaleontological identifications. Besides, these authors proposed erroneous paleoecological interpretations (based on ostracodes and foraminifers) and geographical connections with the Amazon Basin (Pebas/ Solimões Formation) without support from the extensive knowledge on the very diversified and abundant non-marine coeval calcareous microfauna studied in Brazil (Purper, 1977, 1979; Purper \& Pinto, 1983; Purper \& Ornellas, 1991; Ramos, 2006) and Peru and Colombia (Muñoz-Torres et al., 1998, 2006; Whatley et al., 1998, 2000; Swain, 1998). As discussed in the ostracode taxonomy of the present paper (see discussion of Cyprideis spp.), the majority of the ostracodes identified by Hulka et al. (2006:fig.11A-D) are misinterpretations. As argued above, the ostracod genus Cyprideis typically inhabits brackish water with some euryhaline species. In the same way, Heterocypris (see Fig. 10 in the report of Hulka et al., 2006) is a non-marine ostracode genus. On the other hand, the foraminifers identified by Hulka et al. (2006:fig.12A-F) are also mistakes. The specimens $\mathrm{A}, \mathrm{C}$ and $\mathrm{F}$, identified as Cibicidoides cushmani (A), Cibicidoides mckannai (C) and Pseudoparelle california (sic), in fact are specimens of the ubiquitous brackish water genus Ammonia. The remainder three specimens (B, D and E) are also erroneously classified, but based on the poor optical photographs presented, it is almost impossible to get a reliable classification for any of them. As a consequence of these misinterpretations on the well- diversified and abundant non-marine calcareous microfossils from the Pebas/Solimões Formation (most of them cited above), the results, hypothesis and conclusions of the study by Hulka et al. (2006)should be taken with caution.

\section{ACKOWLEDGMENTS}

The authors are indebted to C. T. Bergue for his comments, criticism and advice in the improvement of this paper. We are grateful to A. L. Carreño and V. P. Barbosa for the discussion on the foraminiferal taxonomy. JCC gratefully acknowledges the Conselho Nacional de Desenvolvimento Científico e Tecnológico the finnantial support (proc. 305537/2006-7).

\section{REFERENCES}

Aceñolaza, F.G. \& Sprechmann, P. 2002. The Miocene marine transgression in the meridional Atlantic of South America. Neues Jahrbuch für Geologie und Paläontologie, Abhandlungen, 225:75-84.

Alonso, R. 2000. El terciario de la Puna en tiempos de la ingresión marina paranense. In: F.G. Aceñolaza \& R. Herbst (eds.) Serie Correlación Geológica n. 14 - El Neógeno de Argentina, Tucumán, INSUGEO, p. 163-179.

Bertels, A. \& Zabert, L. 1980. Microfauna del Grupo Santa Maria (Terciarico superior) en las provincias de Catamarca y Tucuman, Republica Argentina. In: Congreso Argentino de Paleontología y Bioestratigrafia/Congreso Latinoamericano de Paleontología, 2/1, 1978. Actas, Buenos Aires, 6:67-73.

Bold van den, W.A. 1976. Distribution of species of the tribe Cyprideidini (Ostracoda, Cytherideidae) in the Neogene of the Caribbean. Micropaleontology, 22:1-43.

Boltovskoy, E. 1990. Morphological variations of benthic foraminiferal tests in response to change in ecological parameters: a review. Journal of Paleontology, 65:175-185.

Boltovskoy, E. 1991. Ihering's hypothesis in the light of foraminiferological data. Lethaia, 24:191-198.

Branisa, L. 1970. La Formación Yecua y los problemas que plantea. Boletín de la Sociedad Geológica Boliviana, 13:20-29.

Geslin, E.; Debenay, J.-P. \& Lesourd, M. 1998. Abnormal wall textures and test deformation in Ammonia (hyaline foraminifer). Journal of Foraminiferal Research, 28:148-156.

Hovikoski, J.; Räsänen, M.; Gingras, M.; Lopéz, S.; Romero, L.; Ranzi, A. \& Melo, J. 2007. Palaeogeographical implications of the Miocene Quendeque Formation (Bolivia) and tidallyinfluenced strata in southwestern Amazonia. Palaeogeography, Palaeoclimatology, Palaeoecology, 243:23-41.

Hulka, C.; Gräfe, K.-U; Sames, B.; Uba, C.E. \& Heubeck, C. 2006 Depositional setting of the Middle to Late Miocene Yecua Formation of the Chaco Foreland Basin, southern Bolivia. Journal of South American Earth Sciences, 21:135-150.

Klie, W. 1939. Brackwasserostracoden von Nordostbrasilien. Zoologische Jahrbucher, Abteilung für Systematik, Geographie und Biologie der Tiere, 72:364-365.

Liebau, A. 2005. A revised classification of the higher taxa of the Ostracoda (Crustacea). Hydrobiologia, 538:115-137.

Madeira-Falcetta, M. 1974. Ecological distribution of the thecamoebal and foraminiferal associations in the mixohaline environment of the southern Brazilian litoral. Anais da Academia Brasileira de Ciências, 46:667-687.

Marengo, H.G. 2000. Rasgos micropaleontológicos de los depósitos de la transgressión Entrerriense-Paranense en la cuenca 
Chaco-Paranense y Noroeste Argentino. In: F.G. Aceñolaza \& R. Herbst (eds.) Serie Correlación Geológica n. 14 - El Neógeno de Argentina, Tucumán, INSUGEO, p. 29-45.

Marshall, L.G.; Sempere, T. \& Gayet, M. 1993. The Petaca (late Oligocene-middle Miocene) and Yecua (late Miocene) formations of the sub-Andean-Chaco basin, Bolivia, and their tectonic significance. Documents du Laboratoire de Géologie de Lyon, 125:291-301.

Muñoz-Torres, F.A.; Whatley, R.C. \& Van Harten, D. 1998. The endemic non-marine Miocene ostracod fauna of the upper Amazon basin. Revista Española de Micropaleontología, 30:89105.

Muñoz-Torres, F.A.; Whatley, R.C. \& Van Harten, D. 2006. Miocene ostracod (Crustacea) bioestratigraphy of the upper Amazon Basin and evolution of the genus Cyprideis. Journal of South American Earth Sciences, 21:75-86.

Padula, L.E. \& Reyes, F.C. 1958. Contribución al Léxico Estratigráfico de las Sierras Subandinas, República de Bolívia. Boletín Técnico de YPFB, 1:9-70.

Pinto, I. \& Ornellas, L.P. 1970. A new brackishwater ostracode Perissocytheridea krömmelbeini Pinto \& Ornellas, sp. nov., from southern Brazil. Escola de Geologia de Porto Alegre, Publicação Especial, 20:1-19.

Purper, I. 1977. Some ostracodes from the Upper Amazon Basin, Brazil. In: H. Loeffler \& D. Danielopol (eds.) Aspects of ecology and zoogeography of recent and fossil Ostracoda, W. Junk Publishers, p. 353-367.

Purper, I. 1979. Cenozoic ostracodes of the Upper Amazon Basin, Brazil. Pesquisas, 12:209-281.

Purper, I. \& Ornellas, L.P. 1991. New ostracodes of endemic fauna of the Pebas Formation, Upper Amazon Basin, Brazil. Pesquisas, 18:25-30.

Purper, I. \& Pinto, I.D. 1983. New genera and species of ostracodes of the Upper Amazon Basin. Pesquisas, 15:113-126.

Ramos, I.F. 2006. Ostracods from the Neogene Solimões Formation (Amazonas, Brazil). Journal of South American Earth Sciences, 21:87-95.
Rossi de García, E. 1966. Contribución al conocimiento de los ostrácodos de la Argentina, Formación Entre Rios, Victoria. Revista de la Associación Geológica Argentina, 21:194-208.

Sanguinetti, Y.T.; Ornellas, L.P. \& Coimbra, J.C. 1992. Post Miocene ostracodes from Pelotas Basin, southern Brazil. Taxonomy. Part. II. Pesquisas, 19:155-156.

Sempere, T. 1995. Phanerozoic evolution of Bolivia and adjacent regions. AAPG Memoir, 62:207-230.

Sheppard, L. \& Bate, R. 1980. Plio-Pleistocene ostracods from the Upper Amazon of Colombia and Peru. Palaeontology, 23:97-124.

Swain, F.M. 1998. Ostracoda from the Pliocene? Pebas Formation at Iquitos, Peru. Available at $<$ http://www.geo.umn.edu/people/ profs/swain/iquitos Peru.pdf $>$.

Uba, C.E. 2005. The Neogene Chaco foreland basin, Bolivia: its evolution as related to Andean tectonics. In: International Symposium on Andean Geodynamics, 2005. Proceedings, Barcelona, 6:746-748.

Whatley, R.C.; Muñoz-Torres, F. \& Harten, D. van. 1998. The Ostracoda of an isolated Neogene saline lake in the western Amazon Basin. In: S. Crasquin-Soleau; E. Braccini \& F. Lethiers (eds.) What about Ostracoda!, Elf Exploration ProductionÉditions, p. 231-245.

Whatley, R.C.; Muñoz-Torres, F. \& Harten, D. van. 2000. Skopaeocythere: a minute new limnocytherid (Crustacea, Ostracoda) from the Neogene of the Amazon Basin. Ameghiniana, 37:163-167.

Wouters, K. \& Martens, K. 1992. Contribution to the knowledge of the tanganyikan cytheraceans, with the description of Mesocyprideis nom. nov. (Crustacea, Ostracoda). Bulletin Koninlikkijk Belgisch Instituut voor Natuurwetenschappen, Biologie, 62:159-166.

Wouters, K. \& Martens, K. 1994. Contribution to the knowledge of the Cyprideis species flock (Crustacea, Ostracoda) of Lake Tanganyika, with the description of three new species. Bulletin Koninlikkijk Belgisch Instituut voor Natuurwetenschappen, Biologie, 64:111-128

Zabert, L.L. 1978. Micropaleontología de la Formación Parana (Mioceno superior) en él subsuelo de la Provincia de Santa Fé, Republica Argentina. Facena, 2:101-165.

Received in September, 2008; accepted in November, 2008. 